\title{
Rabbit model of intervertebral disc degeneration by external compression device characterized by X-ray, MRI, histology, and cell viability
}

\author{
Ismail", Hee Hwan $\mathrm{Tak}^{f}$, James CH Goh ${ }^{f}$, Wang Shih Chang ${ }^{\infty}$, Wong Hee $\mathrm{Kit}^{f}$
}

\begin{abstract}
Appropriate experimental animal models, which mimic the degenerative process occurring in human intervertebral disc (IVD) breakdown and can be used for new treatment studies such as tissue engineering or disc distraction are lacking. We studied the external compression device that used by Kroeber et al to create intervertebral disc degeneration in rabbit model characterized by $X$ ray, MRI, Histology, and Cell Viability. Ten NZW rabbit were randomly assigned to one of five groups. Intervertebral disc VL4-L5 are compressed using an external loading device, $1.9 \mathrm{MPa}$. First group rabbit are loaded for 14 days, second loaded for 28 days, thirth group are loaded for 14 days, and unloaded for 14 days, fourth group loaded for 28 days and unloaded for 28 days. The fifth group, rabbits underwent a sham operation. Additional, rabbits were used as sample for cell viability study. In disc height : sample in group one have biggest decreasing of disc height, that is 23.9 unit. In MRI assessment, the worst grade is grade 3. In histological score, the worst group is group three (58.69), and the best is group 4 (45.69). Group one have the largest dead cell, that are 403.5, and the smallest is group four (124.75). Trypan blue staining showed that group four have better viable cell (91.1) compare than group three (86.4). The study conclude disc degeneration can be created by external axial loading for 14 days in rabbit intervertebral disc. Duration of 28 days unloading gave better result for cells to recover. (Med J Indones 2006; 15:199-207)
\end{abstract}

\begin{abstract}
Abstrak
Model hewan eksperimental yang memadai dan menyerupai proses degeneratif diskus intervertebralis manusia, dan sekaligus digunakan sebagai studi terapi baru seperti rekayasa jaringan atau distraksi diskus masih kurang. Kita meneliti tentang penggunaan alat kompresi eksterna cara Kroeber dkk untuk membuat degenerasi diskus intervertebralis pada model kelinici yang dibuktikan secara sinar X, MRI, histologis, dan viabilitas sel. Sepuluh kelinci putih selandia baru secara acak dibagi menjadi lima grup. Diskus intervertebralis lumbar 4-5 dikompresi 1,9 MPa dengan alat kompresi eksterna. Grup satu kelinci dikompresi selama 14 hari, grup dua selama 28 hari, grup tiga dikompresi 14 hari dan 14 hari dilepaskan kompresi, grup empat 28 hari kompresi, 28 hari tanpa kompresi. Grup lima, kelinci dipasang alat tapi tanpa dikompresi. Empat kelinci lain digunakan sebagai sampel untuk studi viabilitas sel. Penurunan ketinggian diskus terbesar pada grup satu, sebesar 23,9 unit. degenerasi diskus secara MRI yang terjelek adalah derajat tiga. Skor histologis terjelek pada grup tiga (58,69), yang terbaik grup empat (45.69). Kematian sel terbanyak terjadi pada grup satu (403,5), dan terkecil pada grup empat (124,75). Pewarnaan Trypan blue menunjukkan bahwa pada grup empat $(91,1)$ memiliki sel hidup lebih besar daripada grup tiga (86,4). Studi menyimpulkan degenerasi diskus dapat dikreasi dengan kompresi aksial eksterna selama 14 hari pada kelinci. Lama tanpa kompresi 28 hari memberikan hasil lebih baik untuk pemulihan sel. (Med J Indones 2006; 15:199-207)
\end{abstract}

Keywords: Rabbit model-intervertebral disc degeneration-external compression device-X-ray, MRI, Histology, and Cell viabilty

Low back pain (LBP) is an epidemic human condition with a major socioeconomic impact, disabling millions of individual each year. ${ }^{1}$ It has been estimated that up to $80 \%$ of the population experiences LBP at some

\footnotetext{
* Division of Orthopaedic and Traumatology, Faculty of Medicine, University of Indonesia, Jakarta, Indonesia

$f$ Department of Orthopaedic Surgery, National University Hospital, Singapore

$\infty$ Department of Diagnostic Imaging, National University Hospital, Singapore
}

time. ${ }^{2,3}$ Among the various causes of LBP, Intervertebral disc degeneration (IDD) has been estimated to be involved in approximately $39 \%$ of cases. ${ }^{2,4}$

Conceptually, disc degeneration is a product of lifelong degradation with synchronized remodeling of the disc and neighboring vertebrae, including simultaneous adaptation of the disc structures to changes in physical loading and healing from the occasional injury with scar tissue formation. ${ }^{5}$ IDD is a multifaceted, chronic process involving certain detrimental, progressive 
changes in disc composition, structure, and function occurring more quickly and or with greater severity than those associated with normal aging. ${ }^{6}$ IDD is characterized by a complex set of morphologic, biochemical, and biologic changes leading to mechanical dysfunction, and in many cases, pain. Common features associated with IDD include nuclear dehydration, proteoglycan depletion, diminished cellularity, anular disorganization, and disruption. ${ }^{7}$

Interestingly, management of Intervertebral Disc Degeneration that are either conservative or surgical fusion ${ }^{2}$ aims to relieve the symptoms as opposed to treating its underlying cause or application of repair methodologies. ${ }^{8}$ A biologic method of reversing or retarding disc degeneration could revolutionize spinal care. ${ }^{9}$

Advancement of any new therapy from laboratory to the spine clinic will require improved understanding of the pathogenesis and pathophysiology of IDD, together with rigorous demonstrations of safety and efficacy in suitable animal models that closely mimic the specific aspects of human IDD being targeted. ${ }^{6}$

There are numerous in vivo animal models, both naturally occurring and experimentally in duced, to study degenerative disease. Spontaneous disc degeneration has been found in the sand rat, ${ }^{10,11}$ pin tail mouse, Chinese hamster, baboon, and certain dogs, but the inability to obtain large numbers of diseased animal curtails widespread use of these models.1 Experimental models of induced degeneration include in sand rat, rabbit, dog, and sheep, and the way to induce was also vary.

Nomura et $\mathrm{al}^{12}$ have used rabbits in a model in which degeneration was induced by aspiration of the nucleus, followed by implantation of intact nucleus pulposus. Injection of cultured cells from the nucleus showed less degeneration than rabbits receiving no treatment.

In 1948, the stabbing of the Intervertebral Disc (IVD) with a scalpel began to used as a tool to cause disc degeneration in animals. Stab models are classified into 2 types : total annular stab model (Lipson and Muir) and superficial anulus injury model. ${ }^{6}$ Osti and Vernon-Roberts used a discrete cut injury to the disc of sheep to induce degeneration. ${ }^{13}$ Animal models have also been used in older protocols that include denucleation of the disc and chymopapain or chondroitinase treatment. ${ }^{6}$ Jason $\mathrm{P}$ Norcross et al created degeneration of IVD by injection of Chondroitinase $\mathrm{ABC}$ (an agent used in some countries to reduce swelling pressure in herniated discs). ${ }^{1}$
In 2005, Koichi Masuda et al ${ }^{14}$ and Satoshi Sobajima et $\mathrm{al}^{6}$ developed mild, reproducible disc degeneration by annulus needle puncture in Rabbit model. This model also proposed by Keun Su Kim et $\mathrm{al}^{15}$ that performed a biochemical and radiologic comparison of 4 disc injury models to produce IDD. They carried out in 2 experiments, first : used intradiscal injection of campthotecin (an apoptotic agent) and second experiment with the needle number 21-gauge was made 3-puncture and the 18-gauge was 1-puncture.

Lotz et $\mathrm{al}^{16}$ have developed an experimental model to induce disc degeneration based on loading of external compression device to mouse tail discs. Forceful bending was found to induce increased cell death, decreased aggrecan gene expression, and tissue organization. ${ }^{10}$ His previous study also suggest that maintenance of appropriate stress within the disc may be an important basis for strategies to mitigate disc degeneration and initiate disc repair. ${ }^{17}$

Colliou et $\mathrm{al}^{18}$ used an external apparatus to apply compression forces to the tail mice.They found that static external forces increased the number of apoptotic cells. Study of Iatridis et $\mathrm{al}^{19}$ used an Illizarov-type apparatus to chronically apply compressive forces and immobilization on discs in a rat tail model caused changes in mechanical properties and composition of tail discs. They not only reduces disc thickness, but also effect stiffness, angular laxity, and disc composition.

Hutton et $\mathrm{al}^{20}$ used coil springs to apply high compressive forces to the lumbar spines of mature dogs for up to 53 weeks and found no degeneration in any visible form. It does produces microscopic and numerical changes, however, in the amounts of proteoglycans and collagen in the nucleus, inner annulus, and outer annulus.

A new in vivo rabbit model was developed by Kroeber et $\mathrm{al}^{18}$ that produces disc degeneration through the application of controlled and quantified axial mechanical load. The study showed that the unloaded intervertebral discs of the rabbits consisted of a layered annulus fibrosus, a cartilaginous endplate, and a nucleus pulposus comparable with those of humans. After 14 and 28 days of loading, the discs demonstrated a significant decrease in disc space. Histologically, disorganization of the architecture of the annulus occurred. The number of dead cells increased significantly in the annulus and cartilage endplate. These changes were not reversible after 28 days of unloading. ${ }^{18}$ 
Although treatments that strategize to repair or regenerate the nucleus pulposus and annulus fibrosus are needed, appropriate experimental animal models, which mimic the degenerative process often occurring in human intervertebral disc (IVD) breakdown and can be used also for pharmacological studies or new biologic interventions such as tissue engineering or disc distraction are lacking., ${ }^{51,22}$

In this paper, we developed the external compression device that used by Kroeber et $\mathrm{al}^{18}$ to create intervertebral disc degeneration in rabbit model characterized by X-ray, MRI, Histology, and Cell Viability. This model was applicated, because the model could be further followed by interventional treatment by bone marrow stromal cells implantation and IVD distraction by modifying the external compression device.

\section{METHODS}

Experimental study, Post Test Only Control Group Design was performed in Animal Holding Unit and Department of
Orthopaedic Surgery, National University of Singapore (NUS)-National University Hospital (NUH), Singapore from May 2004 till april 2005. 10 New Zealand skeletally mature white rabbits weighing an average $3.57 \mathrm{~kg}$ are used for this study. The rabbit were randomly assigned to one of five groups. In each group there are two samples of rabbit. In group one to group four, the discs are compressed using an external loading device. First group rabbit are loaded for 14 days, second loaded for 28 days, thirth group rabbits are loaded for 14 days, and unloaded for 14 days, fourth group loaded for 28 days and unloaded for 28 days. The fifth group, rabbits underwent a sham operation. The external loading device is situated, but they remained unloaded, and they served as control subjects. They will be sacrificed at 14th day. Other 4 rabbits were used as sample for cell viability study for three and four, which each are two rabbits. This additional, because speciments for trypan blue staining (cell viability) have to be brought directly in fresh form and shattered, so they can not be used for other examination.

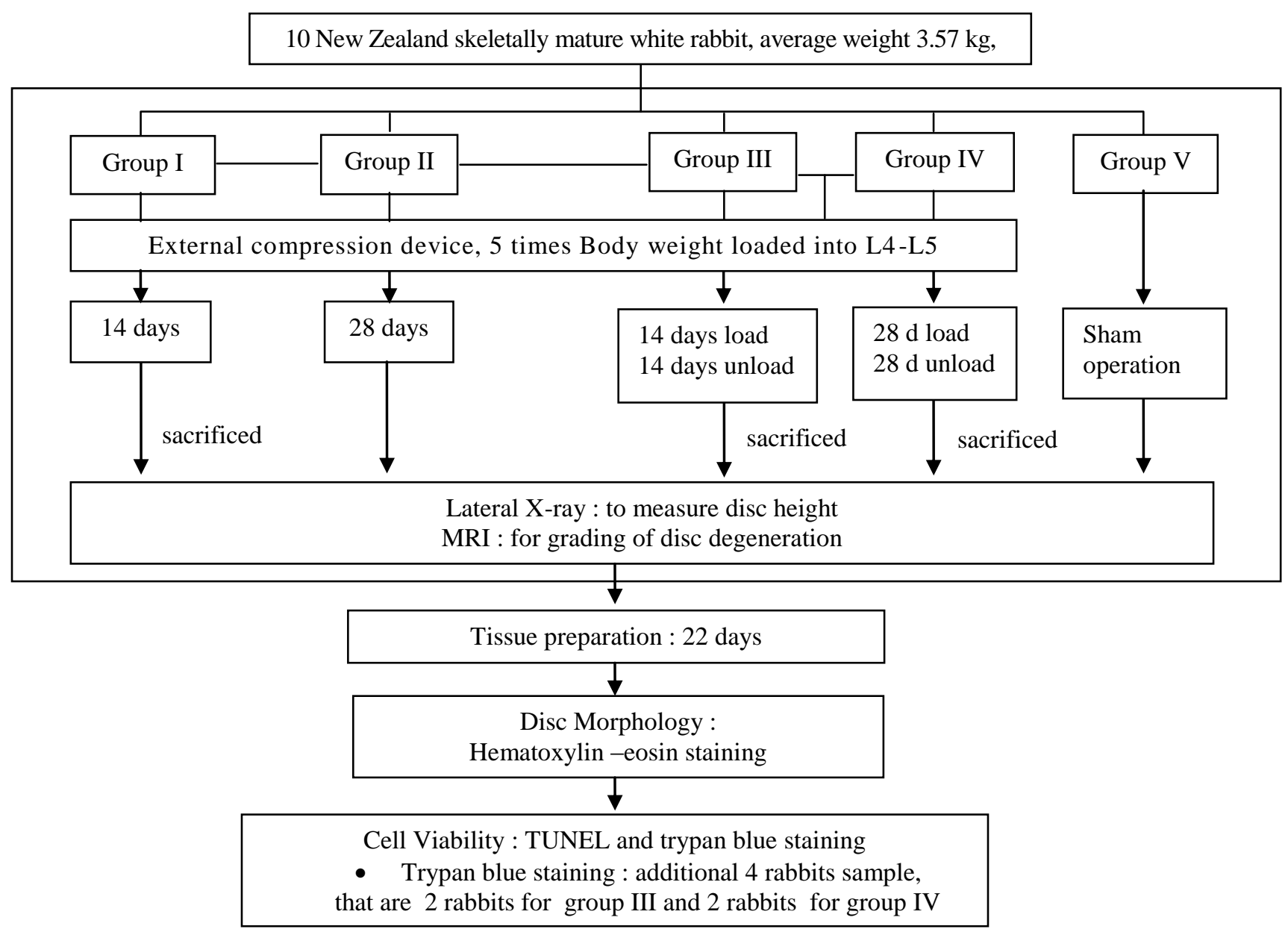




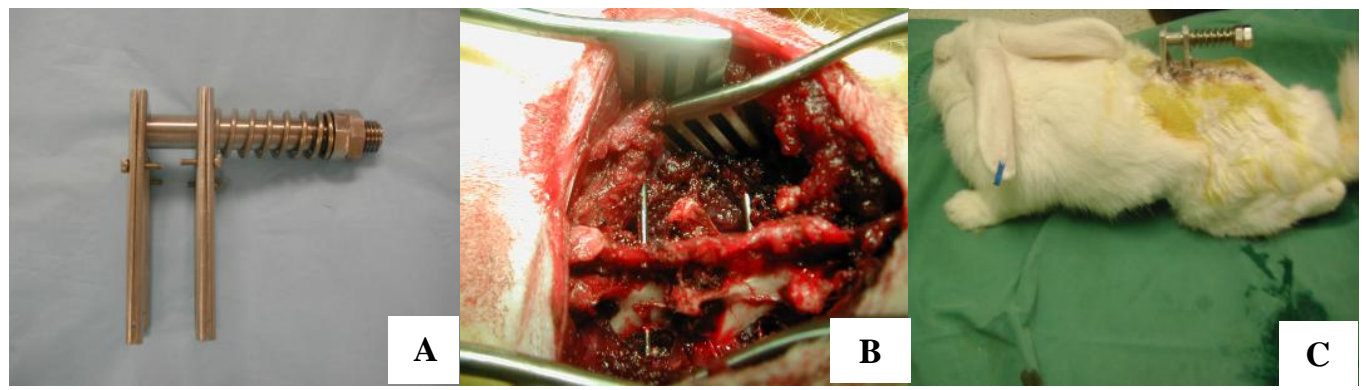

Figure 1. A. external compression device, B. Kirschner wire 1.5 were inserted in VL 4 and 5. C. external compression device has been attached to the K-wire, and applied to VL4 and 5

Tissue preparation. After 14, 28 days of loading, 14 and or 28 days of loading and unloading, the animals were sacrificed and the lumbar spine was harvested for examination. First, the loading device and the Percutaneous pins were removed. The loaded intervertebral disc with adjacent vertebral bodies and the cranial adjacent segment were then dissected using sterile technique. From each dissected segment, firstly they were put in bottle with normal saline solution. The Magnetic Resonance Imaging (MRI) was performed and then a control radiographs was taken with a lateral view.

Next, control and loaded intervertebral discs with adjacent vertebral bodies were placed immediately in 4\% paraformaldehyde and fixed overnight. Decalcification in $30 \%$ fomic acid up to 21 days was followed by dehydration in a graded series of ethanol before paraffin embedding. Sagitally oriented sections were made at 5 to $7 \mu \mathrm{m}$ intervals and placed on silan-coated slides. The sections were stained using hematoxylineosin (H\&E) to demonstrate cell density as well as general morphologic structures. Four midsagittal sections of each disc were stained for dead cells using the TdT-dUTP terminal nick-end labeling (TUNEL) reaction (In Situ cell death detection kit, fluorescin; Boehringer-Manheim, Manheim, Germany).

Magnetic Resonance Imaging (MRI) and Radiology. All the harvested specimens were subjected to MRI and radiologic examination. Magnetic resonance imaging examinations were performed on all the rabbits using a 1.5 -T imager (GE LX Signa, USA) with a quadrature extremity coil receiver. T2-weighted sections in the sagittal plane were obtained in the following settings: fast spin echo sequence with time to repetition (TR) of $4050 \mathrm{msec}$ and time to echo (TE) of $85 \mathrm{msec}$; echo tran lengh :16, received bandwith : $2085 \mathrm{KHz} ; 320$ (h) x 320 (v) matrix; ngx : 20; field of view of 5. The section thickness was $2 \mathrm{~mm}$ with a $0.2 \mathrm{~mm}$ gap. MRI was graded according to the Koichi Masuda et $\mathrm{al}^{14}$ : the modified Thompson classification based on changes in the degree and area of signal intensity from Grade 1 to 4 .

Table 1. MRI grading of Disc Degeneration

\begin{tabular}{ll}
\hline Grade 1 & $\begin{array}{l}\text { normal } \\
\text { minimal decrease of signal intensity but } \\
\text { obvious narrowing of high signal area; }\end{array}$ \\
Grade 3 & $\begin{array}{l}\text { moderate decrease of signal intensity } \\
\text { Grade } 4\end{array}$ \\
\hline
\end{tabular}

Digital lateral radiographs were using GE Senographe DMR+ with senovision system. The setting are : track and filter molybdenum, focal spot $0.1 \mathrm{~mm}$, Kvp $25 \mathrm{~mm}$, AES (automatic Exposure Setting). Each subjected intervertebral disc (L4-L5) with adjacent vertebral bodies and the cranial adjacent segment (L3-L4) was taken. The disc height was measured by enter in radiology centricity programme on which images were could be magnified. Under lateral view, intervertebral disc height was calculated by averaging the measurement obtained from the anterior, middle, and posterior portions of the IVD. Number is in unit (U).

Disc morphology. The disc histology and architecture were analyzed by standard light microscopy (20x Olympus). After preparation of control and loaded intervertebral discs for histology, as previously described, the specimens were scored using Histological scoring developed from histological grading scale of anulus and nucleus pulposus that proposed by Koichi Masuda et $\mathrm{al}^{14}$ (12 points) [table 2] and vertebral end plate was assessed according scoring that developed by Boos $\mathrm{N}$ et al ${ }^{23}$ (18 points) [table 3], and the average of percentage of each points of part of IVD was reported. The bigger the point, the score meaned worse. The assessment of the changes of IVD in three part, that are annulus fibrosus, nucleus pulposus, and vertebral end-plate. 
Table 2. Histological scoring of annulus and nucleus pulposus

I. Anulus fibrosus Grade :

1. Normal, pattern of fibrocartilage lamellae (U-shaped in the posterior aspect and slightly convex in the anterior aspect) without ruptured fibers and without a serpentine appearance anywhere within the annulus

2. Ruptured or serpentined patterned fibers in less than $30 \%$ of the anulus

3. Ruptured or serpentined patterned fibers in more than $30 \%$ at the annulus

II. Border between the anulus fibrosus and nucleus pulposus Grade :

1. Normal

2. Minimally Interrupted

3. Moderate/severe interruption

III. Cellularity at the nucleus pulposus Grade :

1. Normal cellularity with large vacuoles in the gelatinous structure at the matrix

2. Slight decrease in the number at cells and fewer vacuoles

3. Moderate/severe decrease $(>50 \%)$ in the number of cells and in vacuoles

IV. Matrix of the nucleus pulposus Grade :

1. Normal gelatinous appearance

2. Slight condensation of the extracellular matrix

3. Moderate/severe condensation of the extracellular matrix

Histological grading scale based on 4 categories of degenerative changes. Maximum 12 points.

Table 3. Histological scoring of vertebral end-plate

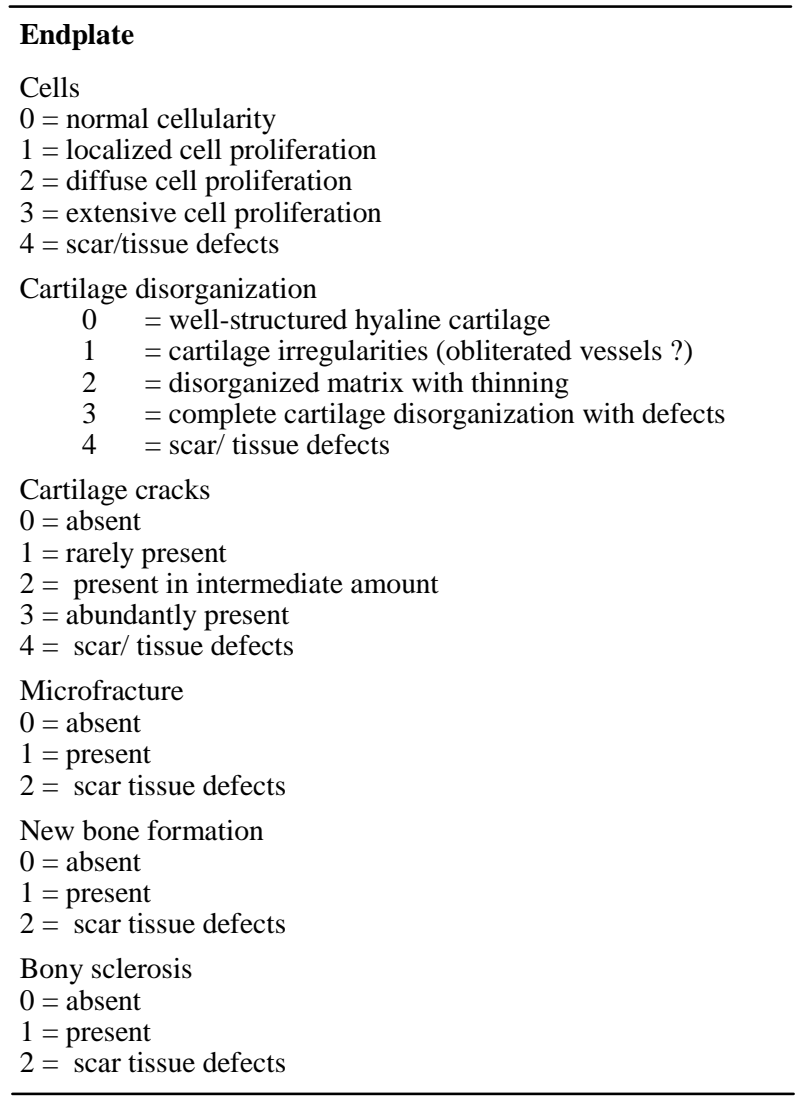

maximum $=18$ points
Cell viability. Quantitative analysis was used to correlate the extent of cell death (TUNEL-positive cells) with the magnitude and duration of loading. The number of cells that were positive by the TUNEL reaction were counted in each section with a fluorescence microscope (Vanox). The TUNEL-positive cells were bright green, and the unaffected cells appeared light red. In combination with the nucleus color the morphology character of the cells also was considered. Typical morphologic features of TUNEL-positive cells are condensation of chromatin, cell nucleus DNA fragmentation, and blebbing. The cells were reported as the average of total number of cells (nucleus pulposus, annulus fibrosus, and end-plate) in the examined disc sections.

Cell viability in the disc loaded for 14 and or 28 days, and unloaded for 14 and or 28 days, was additionally analyzed by releasing the cells from the fresh disc specimen by combined collagenase type $2(2 \mathrm{mg} / \mathrm{ml}) /$ hyaluronidase $(10 \mathrm{mg} / \mathrm{ml})$ digestion overnight. The total number of released cells was determined by trypan blue staining.

\section{RESULTS}

Of 17 animals, 15 survived the complete experiment. One animal from group one was paralyzed, and excluded, so there are 14 rabbits. The external compression device weighed $133 \mathrm{~g}$ and was tolerated well by the animals, because they can move freely in the cages.

Compare to the control group, in disc height : sample in group 1 (14 days loading) have lowest disc height 58.46 unit (U) (figure 2) and biggest decreasing of disc height, that is $23.91 \mathrm{U}$. The group 2 did not show worse decreasing of disc height compare than group 1. Referring to the normal disc (L3-L4), among the experiment group : group 4 have lowest in decreasing of disc height (figure 3). In MRI assessment, among experiment group, grading of group 3 have better result, 1 sample have grade 1 , and another is grade 2 (table 4). Among the experiment and control, the worst grade is grade 3, that are one sample in group one and four (table 4 and fig. 5). 


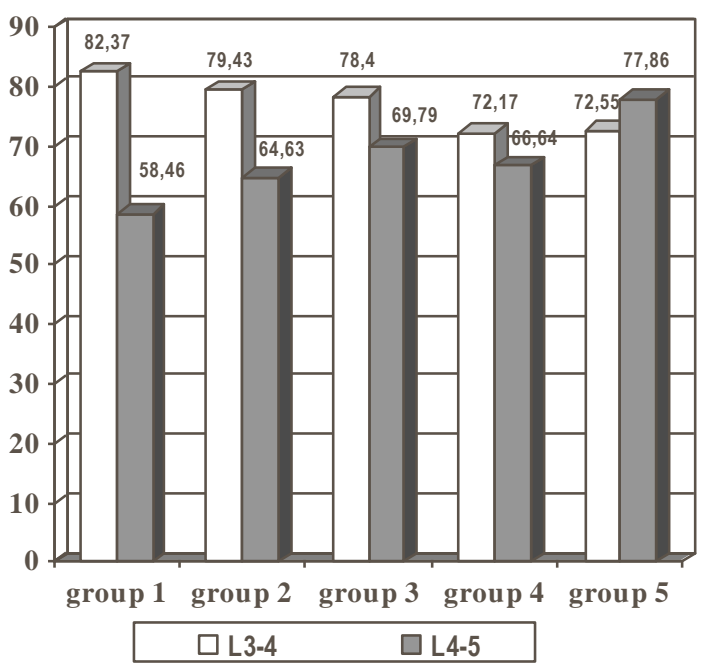

Figure 2. Disc height according to digital $x$-ray

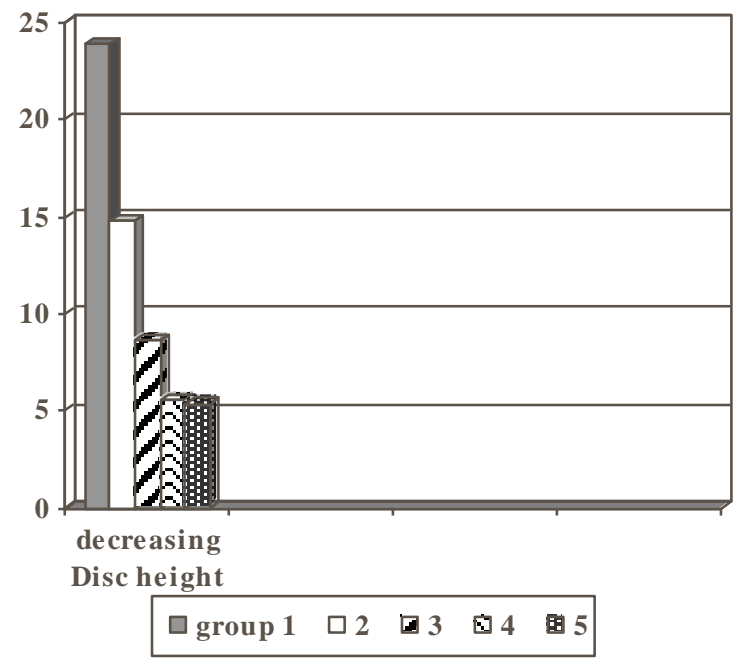

Figure 3. Gap disc thickness/height intervertebral disc Lumbar 4-5 compare to Lumbar 3-4 according to the digital X-ray

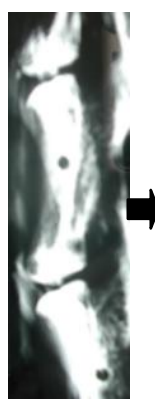

Group 5 (control)
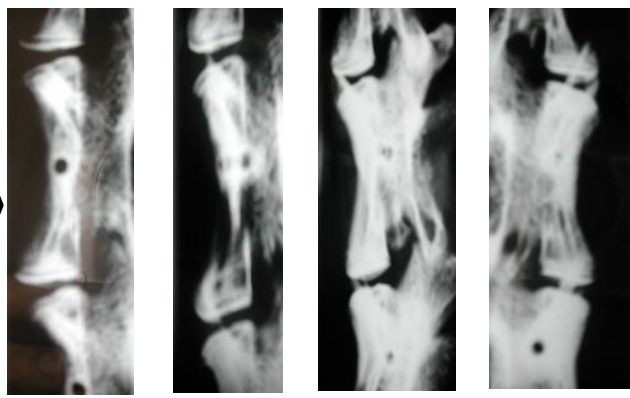

Decreasing of disc height of L4-L5 in group $1,2,3$, and 4
Figure 4. disc height according to the digital $x$-ray

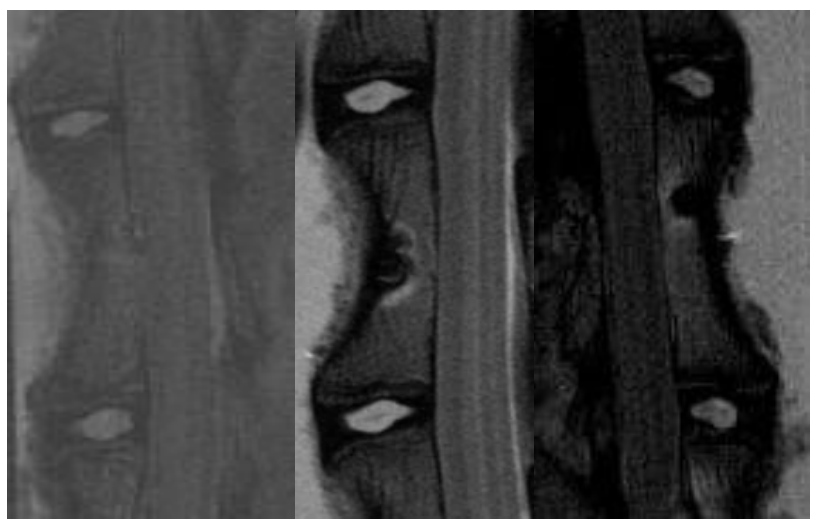

Grade 1

Grade 2

Grade 3

Figure 5. MRI of T2-weighted, midsagital plane image in group 5, that is grade 1, group 1 and 2, the grade is 2, and grade 3 in rabbit group 4 ( 28 days loading and loading)

Table 4. MRI Grading according to the Modified Thompson (Koichi Masuda et al)

\begin{tabular}{|l|l|l|l|l|}
\hline grade & 1 & 2 & 3 & 4 \\
\cline { 1 - 5 } & & & & \\
\cline { 1 - 5 } group & & & & \\
\hline 1 & & 1 & 1 & \\
\hline 2 & & 2 & & \\
\hline 3 & 1 & 1 & & \\
\hline 4 & & 1 & 1 & \\
\hline 5 & 2 & & & \\
\hline
\end{tabular}

Among experiment group, in histological score (figure 6), the worst group is group 3 (58.69), and then group 2 (53.13), and the best group is group 4 (45.69). Histologically in group 3 (fig 6), annulus fibrosus is ruptured or serpentined patterned fibers in less than $30 \%$ of the annulus, border between the anulus fibrosus and nucleus pulposus is minimally Interrupted. Nucleus pulposus cellularity is slight decrease and fewer vacuoles, and slight condensation of the extracellular matrix. In vertebral end plate, there are localized cell proliferation, disorganized matrix with thinning, rarely present of cartilage cracks, new bone formation, and bony sclerosis (fig.7). Microfracture is only found in one sample of group 2.

In dead cell count, group 1 have the largest dead cell, that are 403.5, and the smallest is group 4 (124.75) (figure 8 ). The result is also supported by cell viability test (figure 9). Trypan blue staining showed the group 4 have better viable cell (91.1) compare than group 3 (86.4). 


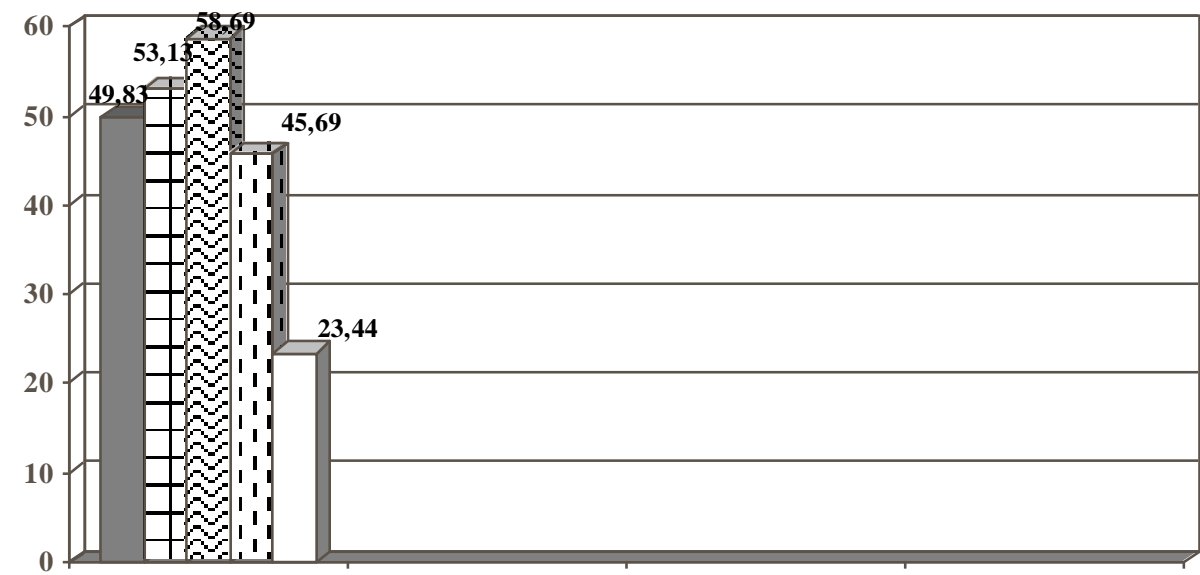

histo score

\begin{tabular}{|lllll|}
\hline group $1 \quad \square$ group 2 & $\square$ group 3 & $\square$ group $4 \quad \square$ group 5 \\
\hline
\end{tabular}

Figure 6. Histological score of disc degeneration
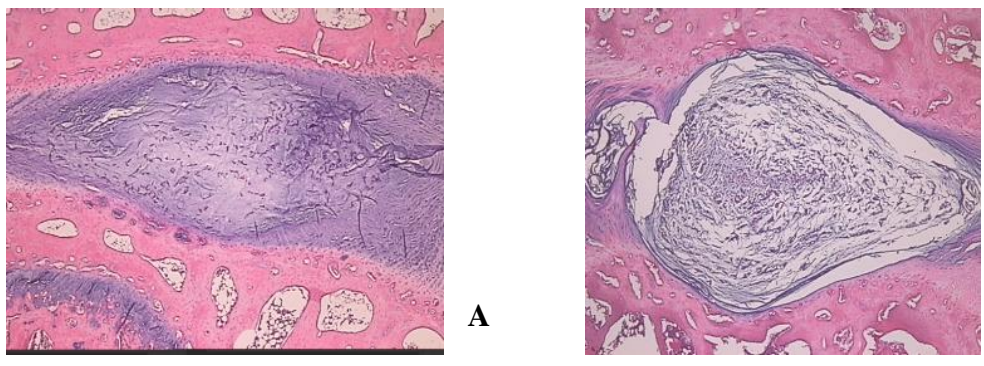

B

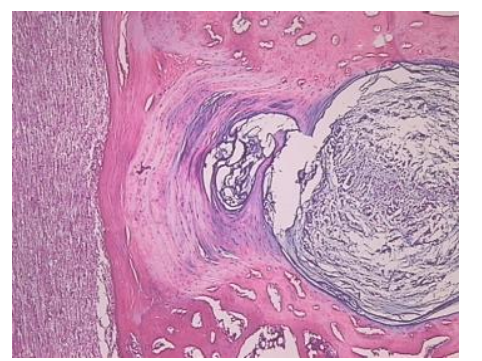

C

Figure 7. disc morphology according hematoxylin-eosin in control group (A), and in group 3 (B. nucleus pulposus appearance), and C (annulus and end-plate)

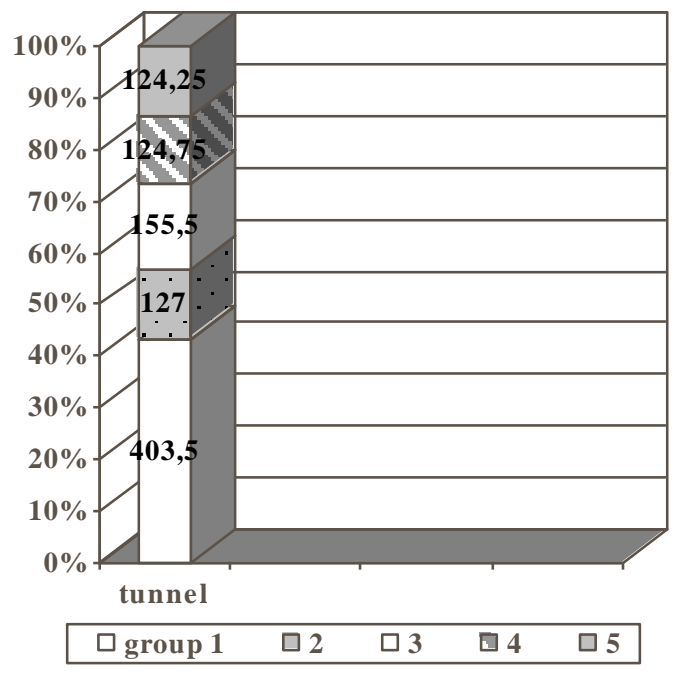

Figure 8. Dead cell according to the TUNEL staining

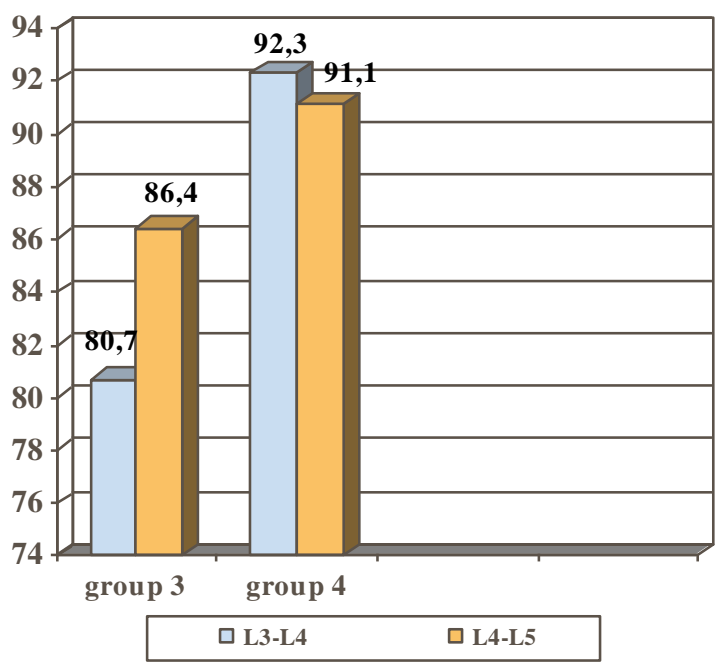

Figure 9. Cell viability according to the trypan blue staining 


\section{DISCUSSIONS}

New Zealand White (NZW) Rabbit was used as a model in this study. This animal is considered a good animal model for IDD, because they match to a number of factors that are important : 1) the animals are easily obtainable and not expensive; 2) the disc should be easy to surgically access and be of adequate size; and 3) the onset of disc degeneration should occur reliable and quite quickly. ${ }^{25}$ The age of sample rabbits is 20-24 weeks with the average weight is $3.57 \mathrm{~kg}$. we use it, because there are no degenerative changes of the intervertebral disc of the New Zealand rabbit up to 24 months age. ${ }^{15}$ Degeneration model was created in which changes pathognomonic of human intervertebral disc degeneration are created by axial compressive loading, and not due to spontaneous or aging process.

Axial compressive loading caused decreasing of disc height. Rabbit in group 1 show have lowest disc height and biggest decreasing of disc height. 14 days loading have already resulted in altered in composition and cellular apoptosis. Dead cell according to the Tunel staining proved it. Sample in group 1 have largest dead cell among the group. Histology score and MRI assessment also supported. Based on Hematoxylin-eosin staining, histology score of group 1 have more that two fold percentage of control group. IDD grading of MRI also showed grade 2 and grade 3 . Grade 3 in this study is the highest grade found among sample.

Logically, rabbits in group 2 that have loaded period of 28 days assumed to have a worse result. But it was not in this study. This possibly caused by inadequate compressive axial loading. We did not control and monitor of spring compressive force in external device. During loading times, spring may be loosened, so it simulate like unloading period. Lotz et al study conclude that maintenance of appropriate stress within the disc may be an important basis for strategies to mitigate disc degeneration and initiate disc repair. ${ }^{17}$

Duration of unloading influenced the viability of the cells. In group 4, although they got loading time for 28 days, they have 28 days unloading for cells recovery. Its Disc height, histology score, TUNEL test showed best result among experiment group. Moreover disc height and dead cells number are relative as same as control group. Group 4 sample also give better result in viable cells compare to the group 3, according to the trypan blue staining. Longer unloading time influence to the cell viability. This result is different to the study of Kroeber et al that they concluded group of animals were loaded for 28 days and unloaded for 28 days lead to a chronic state and the discs can not recover once the loading has been removed. The difference may be caused that our compression loading force has not been sufficient enough to make true cells death. MRI also support that it failed to get grade 4 disc degeneration in this model, according to Koichi Masuda classification. Moreover if we used five grading IDD's Pfirmann et $\mathrm{al},{ }^{25}$ the IDD highest grade is only grade 2 . Other studies also show that disc tissue has a very limited ability to regenerate. We have to modify the external compression device to give adequate force for sufficient cells death in next study. But, beyond that, in unchronic state of compression, duration of unloading have a role in cells recovery.

\section{CONCLUSIONS}

1. The disc degeneration can be created by external axial loading in rabbit intervertebral disc.

2. Duration of 14 days loading has given disc degeneration, the dead cell according to the tunnel test showed the largest number of dead cell among experiment group.

3. Duration of 28 days unloading gave better result for cells to recover, among the experiment group .

4. It was needed larger magnitude of compression force of external compression device, to get significant different among the group in MRI disc degeneration grading.

\section{Acknowledgements}

Special thanks to Yong Soon Chong and dr. Juni Tjahjati for helping in animal handling care and operation, Julee Chan and Abel D. Ang for performing tissue preparation, histology and Tunel staining. We also thank to Louis Tee, Dominic Tey for supporting in spine compactor design, Chong Sue Wee and Low Siew Leng from department of Orthopaedic Surgery, $\mathrm{NUH}$ in evaluating trypan blue staining and Ang Mui Ee and Christopher Au from department Diagnostic Imaging, NUH for performing in digital $\mathrm{x}$-ray and MRI, and last but not least to dr. Nuryati C. Siregar, $\mathrm{SpPA}, \mathrm{PhD}$ (department of pathology anatomy, $\mathrm{CMH}$ ) for assessing Histology score and dr. Bambang Budyatmoko, Sp.Rad (department of radiology, $\mathrm{CMH}$ ) for assessing MRI grading. 


\section{REFERENCES}

1. Norcross JP, Lester GE, Wainhold P, Dahner LE. An invivo model of degenerative disc disease. $J$ orthop Res 2003 ; 21: 183-8.

2. Biyani A, Anderson G BJ, Chaudhary H, An HS. Intradiscal electrothermal therapy: a treatment option in patients with internal disc disruption. Spine 2003; 28(15):S8-S14.

3. Kleinstueck FS, Diederich CJ, Nau WH, Puttlitz CM, Smith JA, Bradford DS, et al. Acute biomechanical and histological effects of intradiscal electrothermal therapy on human lumbar discs. Spine 2001; 26:2198-207.

4. Cohen SP, Larkin T, Abdi S, Chang A, Stojanovic M. Risk factors for failure and complications of intradiscal electrothermal therapy: a pilot study. Spine; 28(11):1142-47.

5. Battie MC, Videman T, Parent E. Lumbar disc degeneration epidemiology and genetic influences. Spine 2005; 29(23):2769-90.

6. Sobajima S, Kompel JF, Kim JS, Wallach CJ, Robertson DD, Vogt MT, et al. A slowly progressive and reproducible animal model of intervertebral disc degeneration characterized by MRI, X-ray, and histology. Spine 2005:30 (1) :15-24.

7. Lotz JC. Animal models of Intervertebral disc degeneration. Spine 2005;9(23):2742-50.

8. Wallach CJ, Sobajima S, Watanabe Y, Kim JS, Georgescu HI, Robbins D, et al. gene transfer of the catabolic inhibitor TIMP-1 increases measured protoglycans in cell from degenerated human intervertebral discs. Spine $2003 ; 28(20): 2331-37$.

9. Yoon ST. the potential of gene therapy for the treatment of disc degeneration. Orthop Clin N Am 2004 ;35: 95-100.

10. Gruber HE, Hanley EN. Recent advances in disc cell biology. Spine 2003;28(2):186-93.

11. Gruber HE, Johnson T, Norton J, Hanley EN. The sand rat model for disc degeneration : radiologic characterization of age-related changes. Spine $2002 ; 27(3): 230-33$.

12. Nomura T, Mochida J, Okuma M, et al. Nucleus pulposus allograft retards intervertebral disc degeneration. Clin Orthop 2001;389:94-101.

13. Osti OL, Vernon-Roberts BFRD. Anulus tears and intervertebral disc degeneration : an experimental study using an animal model. Spine 1990 ;15(8):762-66.
14. Masuda K, Aotaa Y, Muehleman C, Imai Y, Okuma M, Thonar EJ et al. a novel rabbit model of mild, reproducible disc degeneration by an annulus needle puncture : correlation between the degree of disc injury and radiological and histological appearances of disc degeneration. Spine 2005:30 (1) :5-14.

15. Kim KS, Yoon ST, Li J, Park JS, Hutton WC. Disc degeneration in the rabbit : a biochemical and radiological comparison between four disc injury models. Spine 2005:30 (1) :33-7

16. Lotz JC, Chin JR. Intervertebral disc cell death is dependent on the magnitude and duration of spinal loading. Spine 2000:25(12):1477-83.

17. Lotz JC, Colliou OK, Chin JR, Duncan NA, Liedenberg, EBA. Compression-induced degeneration of the intervertebral disc : an in Vivo mouse model and finite-element study. Spine 1998; 23(23):2493-2506.

18. Kroeber MW, Unglaub F, Wang H, Schmid C, Thomsen $\mathrm{M}$, Nerlich A, et al. New in vivo animal model to create intervertebral disc degeneration and to investigate the effects of therapeutic strategies to stimulate disc regeneration. Spine 2002; 27(23):2684-90.

19. Iatridis JC, Mente PL, Stokes IAF, Aronsson DD, Alini $\mathrm{M}$, et al. Compression-induced changes in intervertebral disc properties in a rat tail model. Spine 1999; 24(10): 996-1002.

20. Hutton WC, Ganey TM, Elmer WA, Kozlowska E, Ugbo JL, Doh ES, et al. Does long-term compressive loading on the intervertebral disc cause degeneration?. Spine 2000; 25(23): 2993-3004.

21. An HS, Eugene J, Thonar MA, Masuda K. Biological repair of intervertebral disc. Spine 2003;28(15):S86-92.

22. Cohen SP, Larkin T, Abdi S, Chang A, Stojanovic M. Risk factors for failure and complications of intradiscal electrothermal therapy: a pilot study. Spine; 28(11):1142-47.

23. Boos N, Weisbach S, Rohrbach H, Weiler C, Spratt KF, Nerlich AG. Classification of age-related changes in lumbar interertebral discs : 2002 volvo awards in basic science. Spine 2002;27:2631-24.

24. Unglaub F, Guehring T, Lorenz H, Carstens C, Kroeber MW. Eur Spine J 2005;14:949-55.

25. Christian WA. Pfirrmann, Metzdorf A, Zanetti, M, Hodler, J, and Boos, N. Spine 2001; 26 (17) : 1873-78 . 